\title{
Neurobiology of Comorbid Substance Use Disorders in Mental Illness: A Closer Look at the Underlying Commonalities between Cannabis and Schizophrenia
}

\author{
Rachel A. Rabin • Michelle S. Goodman • \\ Tony P. George • Mera S. Barr
}

Published online: 14 September 2014

(C) Springer International Publishing AG 2014

\begin{abstract}
The high rate of cannabis use disorders (CUDs) among patients with schizophrenia is well established. The implications of this comorbidity are extensive and include symptom exacerbation, frequent relapses leading to hospitalization and an overall worsening of prognosis. Therefore, a greater understanding of why cannabis use and schizophrenia frequently present in the same individual is critical. In this article, we propose that common neurobiological pathways and substrates independently contribute to the predisposition of developing these disorders. Dysregulation of the endocannabinoid system, as well as abnormalities in neurophysiology, neurocognition, genetics, and brain morphology may contribute to this comorbidity. Future studies are needed to confirm these commonalities between CUDs and schizophrenia, given that better understanding of their etiology may guide integrated treatment interventions and the development of prevention strategies for these prevalent comorbid disorders.
\end{abstract}

Keywords Mental illness $\cdot$ Schizophrenia $\cdot$ Drug addiction · Dual diagnosis $\cdot$ Neurocognition

R. A. Rabin · M. S. Goodman · T. P. George

Institute of Medical Science, University of Toronto, 1 King's College

Circle, Room 2374, Toronto, ON M5S 1A8, Canada

R. A. Rabin • M. S. Goodman • T. P. George • M. S. Barr Schizophrenia Division, Centre for Addiction and Mental Health, 250 College Street 7th floor, Toronto, ON M5T 1R8, Canada

T. P. George $\cdot$ M. S. Barr $(\bowtie)$

Department of Psychiatry, University of Toronto, 250 College Street

8th floor, Toronto, ON M5T 1R8, Canada

e-mail: mera.barr@camh.ca

\section{Introduction}

Patients with mental illness suffer from high rates of addiction. For example, an estimated $50 \%$ of patients with schizophrenia meet the criteria for a substance use disorder at some point in their lifetime [1]. Schizophrenia is arguably the most serious of mental illnesses, with approximately $25 \%$ of patients meeting the criteria for a cannabis use disorder (CUD) [2]. CUDs are associated with a wide range of devastating consequences in mentally ill patients. These patients have an earlier mortality rate of approximately 25 years, with an increased vulnerability to medical illness, accidental death, and suicide [3, 4]. Additionally, the severity and prognosis of the primary mental illness, in this case schizophrenia, is often worsened in the context of CUDs. For example, cannabis use has been associated with symptom exacerbation, higher relapse rates, and poor treatment outcome, including medication non-compliance $[5,6]$.

Many theories have been proposed to help explain the high prevalence of substance use among mentally ill patients. The self-medication hypothesis posits that patients use substances in order to alleviate undesirable symptoms associated with the primary illness (i.e. depression, anxiety, negative symptoms) or attenuate side effects from medication used to treat the disorder [7]. However, there is a lack of empirical evidence supporting this hypothesis. By contrast, the addiction vulnerability hypothesis $(\mathrm{AVH})$ theorizes that rather than being a compensatory reaction to the symptoms of psychiatric illness, substance use may be a clinical manifestation of the disorder [8]. Specifically, the neural circuitry mediating reward and positive reinforcement may be disrupted in individuals with mental illness, which could contribute to enhanced vulnerability to addiction. Thus, the same pathophysiology that increases the risk of mental illness also increases vulnerability to drug addiction, thereby rendering high rates of comorbidity. Among schizophrenia patients, dysregulation of hippocampalprefrontal dopamine release in the nucleus accumbens (NAcc) 
compromises executive-inhibitory regulation of motivational processes resulting in a robust response to drugs and associated stimuli, thus predisposing one to both psychotic symptoms and addiction [8]. This theory thus supports a neurobiological link between schizophrenia and CUDs.

There are striking similarities between schizophrenia and CUDs. For example: (1) disease onset during adolescence; (2) cognitive impairment; (3) impulsivity and poor decision making; and (4) low motivation [9-12]. Given these similar phenotypes, overlapping neurobiological substrates and neurocircuitry may independently underlie the development of comorbid CUDs in schizophrenia. In this review, we outline the neurobiology of the endocannabinoid (eCB) system and provide evidence for its dysregulation in schizophrenia and CUDs. In the following sections we discuss abnormalities in neurophysiology and neurocognition, genetic variants, and brain morphology that may also contribute to this comorbidity.

\section{The Endocannabinoid (eCB) System: Relationship to Comorbidity}

\section{Neurobiology of the eCB System}

Cannabis acts on the eCB system and is one of the most abundant neuromodulatory systems in the brain. While delta9-tetrahydrocannabinol (THC) is the primary psychoactive component in cannabis, over 400 additional chemical components including cannabidiol (CBD), and cannabinol are also present in its preparation [13]. In the brain, THC causes pleasurable and psychotropic effects, including feelings of euphoria, relaxation, anxiety, paranoia and, notably, cognitive dysfunction [14]. THC also causes activation of the mesolimbic dopamine system, which mediates the reinforcing and rewarding properties of the drug [15]. Adverse health effects of chronic cannabis use include cancer, bronchitis, and emphysema [16].

The eCB system is comprised of two G protein-coupled receptor subtypes - cannabinoid 1 receptors (CB1R) and cannabinoid 2 receptors (CB2R). Cannabis, cannabis-related drugs, and eCBs act primarily at these receptors. CB1R are the most abundant $\mathrm{G}$ protein-coupled receptors in the human brain. Stimulation of these receptors induce a series of intracellular events, namely modulation of calcium and potassium currents, inhibition of adenylyl cyclase and activation of kinase proteins, which in turn regulate transcription factors.

CB1R are populated in high densities in the hippocampus, NAcc, the dorsal striatum, and cerebellum, and moderate to low densities are present in the amygdala and cerebral cortex [17]. Within these brain regions, CB1R are predominantly located presynaptically on gamma-amniobutyric acid (GABA)ergic (inhibitory) interneurons and glutamatergic (excitatory) neurons. Arachidonoyl ethanolamide (anandamide) and 2-arachidonoyl glycerol are considered the two primary endogenous mediators of cannabinoid signaling, with the latter playing a more vital and integral role in neuroplasticity. eCBs are rapidly inactivated by the enzyme fatty acid amide hydrolase (FAAH) [18]. CB1R efficiently modulate both excitatory and inhibitory transmission at central synapses. These receptors are implicated in multiple forms of neuroplasticity, another mechanism underlying the pathophysiology of both schizophrenia and CUDs [19].

\section{Could Dysfunction of the eCB System Explain CUD Comorbidity in Schizophrenia?}

Deleterious effects of cannabis use in schizophrenia have been linked to underlying disturbances in eCB signaling in the brain and this may, in part, be due to genetic variation of cannabinoid-related genes. The cannabinoid receptor gene (CNR1), which encodes CB1R, modulates striatal response to rewarding stimuli [20], and polymorphisms of this gene may influence the development of this comorbidity [21, 22]. A polymorphic triplet repeat (AAT) nearby the CNR1 gene has been linked to schizophrenia (hebephrenic subtype) in Japanese [23] and Spanish [24] populations and in individuals with addictive disorders [25]. Few studies have examined single-nucleotide polymorphisms (SNPs) in CNR1. While some studies do not support an association between CNR1 polymorphisms in schizophrenia and cannabis use [26, 27], other data suggest that heavy cannabis use in conjunction with specific CNR1 gene variants (rs12720071-G-allele carriers) contributes to greater white matter brain volume and cognitive deficits in patients [28••]. Thus, these variants may predispose patients to engage in heavy cannabis use, which may then exacerbate already-present cognitive impairments.

CB1R density may mediate the magnitude of eCB-mediated neuroplasticity as well as the ability of a CB1R agonist to suppress inhibitory activity [29]; thus, the introduction of cannabis in individuals with altered receptor levels may have critical neurobiological consequences. Post-mortem brain and imaging studies have reported increased CB1R densities in the dorsolateral prefrontal cortex (DLPFC) [30], NAcc, and anterior and posterior cingulate cortex [31] in schizophrenia patients. Augmented CB1R levels have also been reported in the caudate putamen in those with detectable levels of THC in their blood at autopsy irrespective of a diagnosis of schizophrenia [30].

However, there are contradictory reports suggesting that CB1Rs are unchanged in schizophrenia patients and that cannabis exposure has no effect on CB1R density in schizophrenia $[32,33]$. A very recent study reveals methodological confounds that may explain inconsistent findings. Using the novel CB1R selective ligand $\left[{ }^{3} \mathrm{H}\right]-\mathrm{OMAR}$, Volk et al. reported that schizophrenia patients with lower CB1R messenger RNA (mRNA) and protein immunoreactivity levels also have higher levels of $\left[{ }^{3} \mathrm{H}\right]$-OMAR binding to $\mathrm{CB} 1 \mathrm{R}$. Therefore, greater $\mathrm{CB} 1 \mathrm{R}$ receptor availability may contribute to the 
increased susceptibility of schizophrenia subjects to the deleterious effects of cannabis use [34••].

Elevated anandamide has been documented in the cerebrospinal fluid (CSF) of both prodromal and untreated schizophrenia patients, as well as in the blood of patients in the acute phase of schizophrenia $[35,36]$. In contrast, heavy cannabis use in controls is associated with lower CSF anandamide levels [37]. In comorbid patients, both increased anandamide levels (substance-using patients, including cannabis) [38] and decreased anandamide levels (cannabis-using patients) [39] compared with controls and non-using patients, have been reported. Interestingly, CBD, which has antipsychotic, antiaddictive and pro-cognitive properties, was recently demonstrated to increase anandamide levels in schizophrenia patients [40]. Anandamide may 'protect' against hyperdopaminergia [36] and FAAH, the enzyme responsible for anandamide degradation, may serve to compensate for increased anandamide levels [35]. Given that increased anandamide levels are not observed in controls, a hyperactive eCB system specific to patients may be a predisposing factor triggering cannabis use among this population.

In summary, while inconsistencies exist with respect to the association between the eCB system and CUDs in schizophrenia patients, it is apparent that there are alterations in the eCB system and its signaling that may contribute to comorbid cannabis use in schizophrenia. Variants of eCB-related genes, altered levels of circulating anandamide levels and CB1R density, as well as their affinities, should be investigated further to better determine their role in schizophrenia and CUDs.

\section{Clinical and Neurobiological Factors That May Contribute to Cannabis Comorbidity in Schizophrenia}

In the following sections we will review evidence suggesting that neurophysiological, neurocognitive, genetic, and brain morphological abnormalities may contribute to the comorbidity of CUDs in schizophrenia.

\section{Neurophysiology}

Studies have documented neurophysiological impairments in both schizophrenia patients and otherwise healthy cannabis users. Transcranial magnetic stimulation (TMS) is a noninvasive technique that is used to index cortical inhibition and excitability. Moreover, $\mathrm{GABA}_{\mathrm{A}}$ and $\mathrm{GABA}_{\mathrm{B}}$ receptormediated inhibitory neurotransmission can be differentially indexed through single and paired TMS protocols. Among patients with schizophrenia, several studies have demonstrated pervasive cortical inhibition deficits. For example, Daskalakis et al. [41] reported pervasive $\mathrm{GABA}_{\mathrm{B}}$ deficits in the motor and DLPFC using TMS-EEG. In healthy cannabis users, Fitzgerald et al. examined light versus heavy cannabis use in healthy controls, and reported reduced cortical inhibition regardless of cannabis use status [42]. Wobrock et al. [43 • conducted a study in first-episode patients with schizophrenia who used cannabis, and reported deficits in cortical inhibition selective to $\mathrm{GABA}_{\mathrm{A}}$ receptor activity compared with non-using patients. Given that these studies are crosssectional, it is not clear if cannabis produces such deficits. We posit that these deficits in GABA activity increase the likelihood of engaging in cannabis use. Moreover, indices of cortical inhibition have been strongly correlated with working memory performance in healthy subjects and may be important in modulating high-frequency oscillations in the DLPFC that influences working memory [44]. Given that schizophrenia is related to abnormal neural oscillations [45] and that cannabis has been associated with similar impairments, this supports our hypothesis that common underlying substrates may lead to the development of comorbid CUDs in schizophrenia.

Prepulse inhibition (PPI) of the startle response involves an attenuation of responsiveness to a sudden-onset high-intensity stimulus when the stimulus is immediately preceded by a lower-intensity stimulus. PPI is an operational measure of sensorimotor gating that may underlie cognitive symptoms of the schizophrenia [46, 47], but the additional effects of cannabis are less clear. Kedzior and Martin-Iverson [47] impaired attentional modulation and reduced PPI among chronic users relative to controls. Other studies are consistent with these results [48, 49], but not all [50]. In examining the interaction between schizophrenia and cannabis use on PPI, impaired modulation of PPI was demonstrated in schizophrenia patients (users and non-users) and in control users compared with non-cannabis-using controls [51]. PPI deficits are clinically important, given that they may be predictive of or lead to further disruption of cognition [52]. A study conducted by Kedzior et al. [53] suggests that neural oscillations may mediate these deficits, which is expected given that abnormal neural oscillations have been reported in both schizophrenia and CUDs [45, 54].

Amplitude changes in P50 event-related potentials during a dual-click conditioning-testing procedure has been proposed as a neurophysiological marker of deficient sensory gating in schizophrenia [55]. Sensory gating is the brain's ability to modulate its sensitivity to irrelevant sensory stimuli and thus filter out repetitive and redundant sensory stimulation [46]. Cross-sectional studies report both disrupted and intact P50 in cannabis-using schizophrenia patients [56, 57]. Despite the lack of gating differences in these patient studies, it is interesting to note that P50 gating deficits in heavy chronic cannabis users have been linked to abnormal oscillatory activity [58, 59], which is similarly disrupted in schizophrenia patients [45]. 
Taken together, neurophysiology studies suggest that alterations in cortical inhibition, attention and sensory gating may be related to alterations in oscillations mediated by GABAergic inhibitory neurotransmission in both schizophrenia and CUDs. Thus, while further evidence is needed, preliminary data suggest similar underlying pathophysiology exists between schizophrenia and CUDs.

\section{Neurocognition}

Cognitive deficits are core features of schizophrenia, and most prominent impairments are observed in the domains of working and verbal memory and attention. While consistent impairments are seen in non-psychiatric individuals who engage in cannabis use [60], equivocal findings of associations exist between cannabis and schizophrenia. In 2005, D'Souza and colleagues elegantly demonstrated the detrimental effects cannabis has on cognitive performance [5]. Their group showed that cannabis dose-dependently impairs verbal memory and attention in both schizophrenia patients and controls, with the former group having enhanced sensitivity to these effects. While evidence suggests better cognition in cannabisdependent patients compared with non-using patients [61], this does not imply improved cognition as a result of cannabis use. This observation likely reflects that patients who engage in cannabis use have a better premorbid IQ and better social cognition that those who do not $[61,62]$. A recently published study by our group speaks to this effect. We showed that while there is a strong relationship between cannabis consumption and cognitive impairment in current cannabis users, such an association is absent in former users. This suggests that abstinence may reverse cannabis-induced impairments [63•], especially in domains of memory, mediated by the hippocampus, a structure rich in CB1R.

Taken together, similar cognitive deficits are observed in both patients with schizophrenia and with cannabis use in controls, particularly in the attention, working memory, and verbal memory domains.

\section{Genetics}

Genetic variants that influence dopamine represent interesting candidates that may contribute to this comorbidity given its role in schizophrenia [64] and addiction [65]. Catechol-O-methyltransferase (COMT) gene encodes the enzyme responsible for the degradation of dopamine and is essential for dopamine signalling in the prefrontal cortex ( PFC) [66]. COMT activity is genetically polymorphic, with high enzymatic activity in the Val/Val genotype, intermediate activity in the Val/Met genotype, and low activity in the Met/Met genotype; with increased enzymatic activity there is a greater overall reduction in synaptic dopamine availability. Caspi et al. [67] demonstrated that individuals homozygous for the $\mathrm{Val}^{158}$ allele were more likely to display psychotic symptoms and exhibit an earlier age of onset if they used cannabis in adolescence. Henquet et al. [68] showed that patients and their first-degree relatives homozygous for the Val allele showed an increased sensitivity to THC-induced psychotic symptoms and diminished attention and memory. However, this association has not been found in other studies [26] and thus the contribution of COMT to the cannabis-psychosis relationship remains under investigation.

The AKT1 gene codes for a protein kinase that forms an integral part of the dopamine receptor signaling cascade in the striatum [69]. This gene has been linked to schizophrenia [70], and in vitro studies have shown that cannabinoids are capable of stimulating the AKT1 pathway via CB1R [71]. Polymorphisms in this gene may increase the risk of schizophrenia in the presence of cannabis use [72, 73]. These investigators also reported an $A K T 1$-cannabis interaction on cognitive performance in that patients with the $\mathrm{C} / \mathrm{C}$ genotype performed significantly worse on a test of sustained attention compared with T/T carriers [74]. Preliminary experimental evidence has also implicated a different polymorphism of the AKT1 gene (the GG genotype of the SNP rs1130233) as a moderator of sensitivity to the acute psychosisinducing effect of THC [75]. Further characterization of these variants in this comorbidity is warranted.

While single genetic variants represent attractive candidates for increasing vulnerability to comorbidity, current evidence is weak. Analysis of whole genome sequence data may uncover alternative genetic contributors; however, it is likely a number of genes, rather than a single polymorphism or variant of one gene, contribute to comorbidity in schizophrenia. Future genetic research warrants large samples that use prospective designs in order to reach more definitive conclusions regarding the genetic influence on this comorbidity.

\section{Structural Brain Morphology Changes}

Regional and global morphological abnormalities such as ventricular enlargements and decreased brain volume have been documented in the frontal and temporal lobes of patients with schizophrenia [76]. Moreover, morphological changes have been shown to pre-date the first episode of psychosis, suggesting that structural irregularities set the stage for the development of schizophrenia [77].

With respect to associations between cannabis and brain abnormalities, significant volume reductions of the (para-) hippocampus, amygdala, and cerebellum have been reported in adult heavy cannabis users compared with controls [78, 79]. However, a review of other 
studies reports contrary results, suggesting that cannabis use has no effect on gray- or white-matter volume [80].

Among schizophrenia patients, cannabis use reportedly has a detrimental effect on grey-matter density in various brain regions [81, 82]. In adolescent-onset schizophrenia, cannabis use was associated with grey-matter density loss in widespread cortical areas and the cerebellum [83]. A study that focused specifically on the cerebellum demonstrated an addictive effect of having a diagnosis of schizophrenia and cannabis use and schizophrenia on white-matter cerebellar volume loss [84]. However, another study found no differences in brain morphology between cannabis-using and nonusing patients [85].

Among comorbid patients, Smith et al. [86•] examined the relationship of CUDs in at least 6 months of remission on subcortical brain structures in individuals with and without schizophrenia. Shape differences in the dorsal striatum, anterior thalamus, and anteriodorsal and ventral globus pallidus in patients with lifetime CUD were congruent with those observed among the cannabis-using controls; alterations were significantly more pronounced in cannabis-using patients compared with controls. Longitudinally, Rais and colleagues [87] examined the relationship between brain volume-loss over a 5-year interval in first-episode schizophrenia patients $(n=19)$ compared with non-using patients $(n=32)$. Cannabis-using patients demonstrated greater lateral and third ventricle enlargement and grey-matter loss compared with non-using patients and healthy controls.

Brain atrophy may be the consequence of abnormal brain developmental processes that occur during adolescence; thus, deficits are present even before the onset of schizophrenia and cannabis use. Brain volume loss may represent impairment in cortical inhibition and neuroplasticity, thereby adversely affecting maturation of neural circuitries within cortical areas. Reduced synapses, altered dendrites, and lack of generation of new neurons may result due to diminished glutamatergic neurotransmission [88]. Moreover, individuals who develop schizophrenia may be particularly sensitive to brain tissue loss on exposure to cannabis. Future studies should employ prospective designs to determine whether brain volume and white matter loss result in greater risk for using cannabis or whether continuous use of cannabis (versus non-use or abstinence) leads to excessive brain volume loss in schizophrenia.

\section{Discussion}

Data presented here suggest that discrete risk factors converge onto common neural pathways and circuits fostering the initiation and maintenance of comorbid CUDs among patients with schizophrenia. Disturbances in the eCB system, aberrant neurophysiological and neurocognitive processing, genetic variants, and brain atrophy likely predate the onset and are consequences of schizophrenia and CUDs. Moreover, these dysfunctional factors are likely inextricably intertwined; thus, when one is disturbed it likely affects the others, creating a domino effect, and having widespread consequences. See Table 1 for relevant clinical studies addressing the association between cannabis and schizophrenia.

Within the eCB system, CB1Rs are located primarily on GABAergic interneurons, and activation of these presynaptic receptors, either by endogenous or exogenous cannabinoids, leads to a reduction in GABA release by interneurons. This reduction can in turn increase glutamatergic neurotransmission and disrupt the synchronization of pyramidal cell activity leading to abnormal neuroplasticity which underlies neurophysiological processes and, ultimately, cognitive performance [89]. Excess or deficient levels of eCBs, either the result of already present alterations or those due to the introduction of cannabinoids such as THC, can abolish retrograde signaling that underlies eCB-mediated activity, thereby blocking neuroplasticity [90]. Furthermore, developmental studies suggest that anandamide may play a role in determining the direction of neuroplasticity [91]. Both of these mechanisms may result in compromised cognition [92].

Brain atrophy may also be the result of neuroplastic processes gone awry. Brain volume loss in individuals with schizophrenia and/or cannabis use may reflect diminished neuroplasticity, such as reduced number of synapses or altered synapses, thereby preventing full maturation of brain development [88]. Interestingly, measures of cognitive functioning have been shown to correlate with measures of brain structure in both patients with schizophrenia and healthy controls [93].

Cognitive dysfunction has been considered an endophenotype of schizophrenia and given that analogous deficits are well documented in chronic cannabis users [10], and that underlying neurobiological processes contribute to this comorbidity, provides support for the exploration of cognitive function as a biomarker for comorbid cannabis use and schizophrenia. This is important to establish that candidate endophenotypes are crucial tools to help understand and treat such disorders. Such knowledge may also guide individualized treatment approaches. For example, conceivably, CB1R agonists or partial agonists may counteract increased anandamide levels as a result of eCB dysregulation in an attempt to restore homeostatic conditions. Non-pharmacological treatments should also be considered. Brain stimulation 
Table 1 Relevant clinical studies addressing the association between cannabis use and schizophrenia

\begin{tabular}{|c|c|c|c|c|c|}
\hline Author (year) & Study design & Sample & $\begin{array}{l}\text { Neurobiological } \\
\text { target }\end{array}$ & Findings & $\begin{array}{l}\text { Supports common } \\
\text { neurobiological } \\
\text { link of } \\
\text { comorbidity }\end{array}$ \\
\hline \multicolumn{6}{|l|}{ Endocannabinoids } \\
\hline $\begin{array}{l}\text { Potvin et al. } \\
\text { (2008) [38] }\end{array}$ & Longitudinal & $\begin{array}{l}\text { Patients }(n=29): \\
\text { Schizophrenia }(n=16) \\
\text { Schizoaffective } \\
\quad \text { disorder }(n=11) \\
\text { Schizophreniform } \\
\text { disorder }(n=2) \\
\text { Controls }(n=17)\end{array}$ & Anandamide & $\begin{array}{l}\text { Increased anandamide } \\
\text { levels in patients with } \\
\text { comorbid substance } \\
\text { abuse compared with } \\
\text { controls }\end{array}$ & Yes \\
\hline $\begin{array}{l}\text { Leweke et al. } \\
\text { (2007) [39] }\end{array}$ & Cross-sectional & $\begin{array}{l}\text { Patients }(n=44): \\
\text { LFC }(n=55), \text { HFC } \\
\quad(n=26) \\
\text { Controls }(n=81)\end{array}$ & Anandamide & $\begin{array}{l}\text { Greater than tenfold } \\
\text { increase in CSF } \\
\text { anandamide levels } \\
\text { in LFC patients } \\
\text { compared with HFC } \\
\text { patients } \\
\text { LFC and HFC patients } \\
\text { both had higher CSF } \\
\text { anandamide levels } \\
\text { compared with controls }\end{array}$ & Inconclusive \\
\hline \multicolumn{6}{|l|}{ Genetics } \\
\hline $\begin{array}{l}\text { Caspi et al. } \\
\text { (2005) [67] }\end{array}$ & Longitudinal & $\begin{array}{l}N=803 \text { representative } \\
\text { birth cohort }\end{array}$ & $\begin{array}{l}\text { Functional } \\
\text { polymorphism } \\
\text { of COMT }\end{array}$ & $\begin{array}{l}\text { Individuals homozygous } \\
\text { for the Val }{ }^{158} \text { allele } \\
\text { more likely to display } \\
\text { psychotic symptoms, } \\
\text { and at an earlier age, if } \\
\text { they used cannabis in } \\
\text { adolescence }\end{array}$ & Yes \\
\hline $\begin{array}{l}\text { Di Forti et al. } \\
\text { (2012) [73] }\end{array}$ & Case-control & $\begin{array}{l}\text { First-episode psychosis } \\
\quad(n=489) \\
\text { Controls }(n=278)\end{array}$ & $\begin{array}{l}\text { AKT1 (rs2494732) } \\
\text { genotype }\end{array}$ & $\begin{array}{l}\text { In cannabis users, genetic } \\
\text { variation at this AKT1 } \\
\text { locus influences risk of } \\
\text { developing a psychotic } \\
\text { disorder }\end{array}$ & Yes \\
\hline $\begin{array}{l}\text { Henquet et al. } \\
\text { (2006) [68] }\end{array}$ & Cross-sectional & $\begin{array}{l}\text { Patients }(n=30) \\
\text { Relatives of patients } \\
\quad(n=12) \\
\text { Controls }(n=32)\end{array}$ & $\begin{array}{l}\text { Functional } \\
\text { polymorphism } \\
\text { of COMT }\end{array}$ & $\begin{array}{l}\text { Patients and first-degree } \\
\text { relatives homozygous } \\
\text { for Val }{ }^{158} \mathrm{Met} \text { allele } \\
\text { displayed increased } \\
\text { sensitivity to THC-induced } \\
\text { psychotic symptoms and } \\
\text { diminished attention and } \\
\text { memory }\end{array}$ & Yes \\
\hline $\begin{array}{l}\text { Van Winkel et al. } \\
\text { (2011) [74] }\end{array}$ & Cross-sectional & $\begin{array}{l}\text { Patients }(n=611) \text { : } \\
\text { Cannabis users }(n=339) \\
\text { Non-cannabis users } \\
\quad(n=272)\end{array}$ & $\begin{array}{l}\text { Polymorphisms } \\
\text { of AKT1 }\end{array}$ & $\begin{array}{l}\text { Patients with } \mathrm{C} / \mathrm{C} \text { genotype } \\
\text { performed significantly } \\
\text { worse on a sustained- } \\
\text { attention task compared } \\
\text { with } \mathrm{T} / \mathrm{T} \text { carriers }\end{array}$ & Yes \\
\hline $\begin{array}{l}\text { Zammit et al. } \\
\text { (2007) [26] }\end{array}$ & Case-control & $\begin{array}{l}\text { Patients genotyped } \\
\quad \text { for CNR1 }(n=797)\end{array}$ & $\begin{array}{l}\text { Variants within } \\
\text { the CNR1 } \\
\text { gene }\end{array}$ & $\begin{array}{l}\text { Lacking effects of a CNR1 } \\
\text { polymorphism in patients } \\
\text { between non-cannabis } \\
\text { users and self-reported } \\
\text { cannabis users } 1 \text { year prior } \\
\text { to illness onset }\end{array}$ & No \\
\hline \multicolumn{6}{|l|}{ Brain morphology } \\
\hline $\begin{array}{l}\text { Bangalore et al. } \\
\text { (2008) [82] }\end{array}$ & Cross-sectional & $\begin{array}{l}\text { First-episode } \\
\quad \text { schizophrenia } \\
\text { patients }(n=29): \\
\text { Cannabis users }(n=15) \\
\text { Non-cannabis users } \\
\quad(n=24) \\
\text { Controls }(n=42) \text { : } \\
\text { Non-cannabis users only }\end{array}$ & $\begin{array}{l}\text { Dorsolateral } \\
\text { prefrontal cortex, } \\
\text { hippocampus, } \\
\text { posterior cingulate } \\
\text { cortex, and } \\
\text { cerebellum }\end{array}$ & $\begin{array}{l}\text { Decrease in gray-matter } \\
\text { density in the right } \\
\text { posterior cingulate } \\
\text { cortex as a function } \\
\text { of cannabis use }\end{array}$ & Yes \\
\hline $\begin{array}{l}\text { *Rais et al. } \\
\text { (2008) [87] }\end{array}$ & Longitudinal & $\begin{array}{l}\text { Patients }(n=51) \text { : } \\
\text { Cannabis users }(n=19)\end{array}$ & $\begin{array}{l}\text { Total gray and white } \\
\text { cerebrum matter, }\end{array}$ & $\begin{array}{l}\text { Larger third ventricle volumes } \\
\text { found in non-cannabis- }\end{array}$ & Inconclusive \\
\hline
\end{tabular}


Table 1 (continued)

\begin{tabular}{|c|c|c|c|c|c|}
\hline & & $\begin{array}{l}\text { Non-cannabis users }(n=32) \\
\text { Controls }(n=31) \text { : } \\
\text { Non-substance use only }\end{array}$ & $\begin{array}{l}\text { lateral and third } \\
\text { ventricle volumes }\end{array}$ & $\begin{array}{l}\text { using patients compared } \\
\text { with cannabis-using } \\
\text { patients and healthy } \\
\text { controls } \\
\text { Cannabis-using patients } \\
\text { demonstrated greater } \\
\text { lateral and third ventricle } \\
\text { enlargement and gray-matter } \\
\text { loss compared with } \\
\text { non-cannabis-using } \\
\text { patients and healthy } \\
\text { controls }\end{array}$ & \\
\hline $\begin{array}{l}\text { *Smith et al. } \\
\text { (2014) [86•] }\end{array}$ & Cross-sectional & $\begin{array}{l}\text { Patients }(n=43) \text { : } \\
\text { CUD }(n=15) \\
\text { No CUD }(n=28) \\
\text { Controls }(n=54) \text { : } \\
\text { CUD }(n=10) \\
\text { No CUD }(n=44)\end{array}$ & $\begin{array}{l}\text { Striatum, globus } \\
\text { pallidus, thalamus }\end{array}$ & $\begin{array}{l}\text { Structural brain differences } \\
\text { were present in patients } \\
\text { with lifetime CUD } \\
\text { compared with the } \\
\text { CUD control group } \\
\text { Mediodorsal thalamus and } \\
\text { dorsal striatum appeared } \\
\text { more sensitive to the } \\
\text { effects of cannabis in } \\
\text { patients compared } \\
\text { with controls }\end{array}$ & Yes \\
\hline $\begin{array}{l}\text { Solowij et al. } \\
(2011) \text { [84] }\end{array}$ & Cross-sectional & $\begin{array}{l}\text { Patients }(n=17) \text { : } \\
\text { Cannabis users }(n=8) \\
\text { Non-cannabis users } \\
\quad(n=9) \\
\text { Controls }(n=31) \text { : } \\
\text { Cannabis users }(n=15) \\
\text { Non-cannabis users } \\
\quad(n=16)\end{array}$ & $\begin{array}{l}\text { Cerebellar gray and } \\
\text { white matter }\end{array}$ & $\begin{array}{l}\text { Cannabis use and schizophrenia } \\
\text { are independently associated } \\
\text { with smaller cerebellar white- } \\
\text { matter volume } \\
\text { No group differences in } \\
\text { cerebellar gray matter or } \\
\text { total volumes }\end{array}$ & Yes \\
\hline $\begin{array}{l}\text { Szeszko et al. } \\
\text { (2007) [81] }\end{array}$ & Cross-sectional & $\begin{array}{l}\text { Patients }(n=51) \text { : } \\
\text { Cannabis users }(n=20) \\
\text { Non-cannabis users } \\
\quad(n=31) \\
\text { Controls }(n=56) \text { : } \\
\text { Non-substance use only }\end{array}$ & $\begin{array}{l}\text { Anterior cingulate } \\
\text { cortex }\end{array}$ & $\begin{array}{l}\text { Decrease in gray-matter density } \\
\text { in the anterior cingulate } \\
\text { cortex as a function of } \\
\text { cannabis use }\end{array}$ & Yes \\
\hline Author (year) & Study design & Sample & Measure & Findings & $\begin{array}{l}\text { Supports common } \\
\text { neurobiological } \\
\text { link of } \\
\text { comorbidity }\end{array}$ \\
\hline \multicolumn{6}{|l|}{ Neurophysiology } \\
\hline $\begin{array}{l}\text { Rentzsch et al. } \\
\text { (2007) [57] }\end{array}$ & Longitudinal & $\begin{array}{l}\text { Patients }(n=27): \\
\text { Chronic cannabis } \\
\quad \text { abusers }(n=15) \\
\text { Non-cannabis abusers } \\
\quad(n=12) \\
\text { Controls }(n=29) \text { : } \\
\text { Chronic cannabis } \\
\quad \text { abusers }(n=11) \\
\text { Non-cannabis abusers } \\
\quad(n=18)\end{array}$ & P50 & $\begin{array}{l}\text { No differences in P50 sensory } \\
\text { gating between schizophrenia } \\
\text { cannabis abuser and non- } \\
\text { abuser groups or healthy } \\
\text { controls }\end{array}$ & No \\
\hline $\begin{array}{l}\text { Scholes-Balog and } \\
\text { Martin-Iverson } \\
\text { (2011) [51] }\end{array}$ & Cross-sectional & $\begin{array}{l}\text { Patients }(n=64): \\
\text { Cannabis users }(n=20) \\
\text { Non-cannabis users } \\
\quad(n=44) \\
\text { Controls }(n=66): \\
\text { Cannabis users }(n=34) \\
\text { Non-cannabis users } \\
(n=32)\end{array}$ & PPI & $\begin{array}{l}\text { Cannabis-using controls, } \\
\text { patients with and without } \\
\text { cannabis use all demonstrated } \\
\text { impaired modulation of PPI } \\
\text { compared with healthy controls }\end{array}$ & No \\
\hline $\begin{array}{l}\text { *Wobrock et al. } \\
\text { (2010) [43•] }\end{array}$ & Cross-sectional & $\begin{array}{l}\text { Patients }(n=29) \text { : } \\
\text { History of comorbid } \\
\quad \text { cannabis abuse }(n=12) \\
\text { No cannabis abuse } \\
\quad \text { history }(n=17)\end{array}$ & Cortical inhibition & $\begin{array}{l}\text { Reduction in } \mathrm{GABA}_{\mathrm{A}} \text { activity } \\
\text { in patients with a history of } \\
\text { cannabis abuse compared } \\
\text { with non-using patients } \\
\text { No difference in CSP } \\
\text { between groups }\end{array}$ & Yes \\
\hline
\end{tabular}


Table 1 (continued)

\begin{tabular}{|c|c|c|c|c|c|}
\hline Author (year) & Study design & SCZ spectrum & Sample & Findings & $\begin{array}{l}\text { Supports common } \\
\text { neurobiological } \\
\text { link of } \\
\text { comorbidity }\end{array}$ \\
\hline \multicolumn{6}{|l|}{ Neuropsychology } \\
\hline $\begin{array}{l}\text { D'Souza et al. } \\
(2005)[5]\end{array}$ & Crossover & $\begin{array}{l}\text { DSM-IV diagnosis of } \\
\text { schizophrenia or } \\
\text { schizoaffective disorder }\end{array}$ & $\begin{array}{l}\text { All participants } \\
\text { used cannabis at } \\
\text { least once } \\
\text { Patients }(n=13) \\
\text { Controls }(n=22)\end{array}$ & $\begin{array}{l}\text { THC impaired verbal memory } \\
\text { and attention in both patients } \\
\text { and controls. Patients with } \\
\text { schizophrenia also performed } \\
\text { worse than the control group } \\
\text { in these domains }\end{array}$ & Yes \\
\hline $\begin{array}{l}\text { Rabin et al. } \\
\text { (2013) [63•] }\end{array}$ & Cross-sectional & $\begin{array}{l}\text { DSM-IV diagnosis of } \\
\text { schizophrenia or } \\
\text { schizoaffective disorder }\end{array}$ & $\begin{array}{l}\text { Patients: } \\
\text { Cannabis dependence } \\
\quad(n=18) \\
\text { No cannabis } \\
\text { dependence }(n=29) \\
\text { Non cannabis users: } \\
\text { Lifetime dependence } \\
\quad(n=21) \\
\text { No lifetime cannabis } \\
\text { dependence }(n=8)\end{array}$ & $\begin{array}{l}\text { Patients, both current and } \\
\text { former cannabis users, have } \\
\text { superior performance on the } \\
\text { continuous performance test } \\
\text { and on the Trails Making A } \\
\text { test compared with patients } \\
\text { with no history of use }\end{array}$ & Yes \\
\hline
\end{tabular}

* signifies the citations of importance as listed in the manuscript

LFC low-frequency cannabis use, HFC high-frequency cannabis use, COMT Catechol-O-methyltransferase, $C N R 1$ cannabinoid receptor, $C U D$ cannabis use disorder, PPI prepulse inhibition, $C S F$ cerebrospinal fluid, THC delta-9-tetrahydrocannabinol, DSM-IV Diagnostic and Statistical Manual of Mental Disorders, 4th edition

techniques such as repetitive TMS (rTMS) that targets the DLPFC may also be effective in restoring normal eCB signaling and neurotransmitter levels that are disturbances as a result of specific genetic variants.

While technology has advanced immensely in the neurosciences, more research further developing the neurobiological underpinnings between SUDs and other psychiatric illnesses are clearly needed. Studies employing state-of-the art technology with a multidisciplinary approach, both prospectively and longitudinally, should be a focus for future research. While we have examined these potential contributing factors in isolation, it is imperative that these multiple influences be examined simultaneously. Ultimately, it is hoped that appropriate and effective interventions and prevention strategies for these prevalent comorbid disorders can be developed, and the prevalence of individuals suffering from comorbid disorders can be reduced.

\section{Conclusion}

In this review we have highlighted overlapping neurobiological substrates and neurocircuitry that independently underlie the development of comorbid CUDs in schizophrenia. The continued exploration of these and other factors as the molecular mechanisms facilitating this comorbidity will hopefully lead towards a better understanding of the illness and the development of novel therapeutic interventions for addictions, cognitive deficits, and treatment approaches for schizophrenia.

\section{Compliance with Ethics Guidelines}

Conflict of Interest Rachel A. Rabin, Michelle S. Goodman, and Mera S. Barr declare no conflicts of interest. Tony P. George declares a consultancy fee from Novartis and a grant from Pfizer, not related to this article. Human and Animal Rights and Informed Consent This article does not contain any studies with human or animal subjects performed by the author.

\section{References}

Papers of particular interest, published recently, have been highlighted as:

- Of importance

-. Of major importance

1. Regier DA et al. Comorbidity of mental disorders with alcohol and other drug abuse. Results from the Epidemiologic Catchment Area (ECA) Study. JAMA. 1990;264(19):2511-8.

2. Koskinen $\mathrm{J}$ et al. Rate of cannabis use disorders in clinical samples of patients with schizophrenia: a meta-analysis. Schizophr Bull. 2009;36(6):1115.

3. Crump $\mathrm{C}$ et al. Comorbidities and mortality in persons with schizophrenia: a Swedish national cohort study. Am J Psychiatry. 2013;170(3):324-33.

4. Schmidt LM, Hesse M, Lykke J. The impact of substance use disorders on the course of schizophrenia: a 15-year follow-up study: dual diagnosis over 15 years. Schizophr Res. 2011;130(1-3):22833.

5. D'Souza DC et al. Delta-9-tetrahydrocannabinol effects in schizophrenia: implications for cognition, psychosis, and addiction. Biol Psychiatry. 2005;57(6):594-608. 
6. Foti DJ et al. Cannabis use and the course of schizophrenia: 10-year follow-up after first hospitalization. Am J Psychiatry. 2010;167(8): 987-93.

7. Khantzian EJ. The self-medication hypothesis of addictive disorders: focus on heroin and cocaine dependence. Am J Psychiatry. 1985;142(11):1259-64.

8. Chambers RA, Krystal JH, Self DW. A neurobiological basis for substance abuse comorbidity in schizophrenia. Biol Psychiatry. 2001;50(2):71-83.

9. Bossong MG, Niesink RJ. Adolescent brain maturation, the endogenous cannabinoid system and the neurobiology of cannabisinduced schizophrenia. Prog Neurobiol. 2010;92(3):370-85.

10. Solowij N, Michie PT. Cannabis and cognitive dysfunction: parallels with endophenotypes of schizophrenia? J Psychiatry Neurosci. 2007;32(1):30-52.

11. Solowij N, Grenyer BFS. Long-term effects of cannabis on psyche and cognition. In: Grotenhermen F, Russo E, editors. Cannabis and cannabinoids: pharmacology, toxicology, and therapeutic potential. New York: Haworth Press; 2002. p. 299-311.

12. Dervaux A et al. Impulsivity and sensation seeking in cannabis abusing patients with schizophrenia. Schizophr Res. 2010;123(2-3):278-80.

13. Iversen L. The science of marijuana. 2nd ed. Oxford: Oxford University Press; 2008.

14. Adams IB, Martin BR. Cannabis: pharmacology and toxicology in animals and humans. Addiction. 1996;91(11):1585-614.

15. Gardner EL. Endocannabinoid signaling system and brain reward: emphasis on dopamine. Pharmacol Biochem Behav. 2005;81(2): 263-84.

16. Ashton $\mathrm{CH}$. Adverse effects of cannabis and cannabinoids. Br J Anaesth. 1999;83(4):637-49.

17. Herkenham M. Characterization and localization of cannabinoid receptors in brain: an in vitro technique using slide-mounted tissue sections. NIDA Res Monogr. 1991;112:129-45.

18. Piomelli $\mathrm{D}$ et al. Endogenous cannabinoid signaling. Neurobiol Dis. 1998;5(6 Pt B):462-73.

19. Chevaleyre V, Takahashi KA, Castillo PE. Endocannabinoidmediated synaptic plasticity in the CNS. Annu Rev Neurosci. 2006;29:37-76.

20. Chakrabarti B et al. Variations in the human cannabinoid receptor (CNR1) gene modulate striatal responses to happy faces. Eur J Neurosci. 2006;23(7):1944-8

21. Kohn Y, Lerer B. Excitement and confusion on chromosome 6q: the challenges of neuropsychiatric genetics in microcosm. Mol Psychiatry. 2005;10(12):1062-73.

22. Zhang PW et al. Human cannabinoid receptor 1: $5^{\prime}$ exons, candidate regulatory regions, polymorphisms, haplotypes and association with polysubstance abuse. Mol Psychiatry. 2004;9(10):916-31.

23. Ujike $\mathrm{H}$ et al. CNR1, central cannabinoid receptor gene, associated with susceptibility to hebephrenic schizophrenia. Mol Psychiatry. 2002;7(5):515-8.

24. Martinez-Gras I et al. (AAT)n repeat in the cannabinoid receptor gene, CNR1: association with schizophrenia in a Spanish population. Eur Arch Psychiatry Clin Neurosci. 2006;256(7):437-41.

25. Comings DE et al. Cannabinoid receptor gene (CNR1): association with i.v. drug use. Mol Psychiatry. 1997;2(2):161-8.

26. Zammit $\mathrm{S}$ et al. Genotype effects of CHRNA7, CNR1 and COMT in schizophrenia: interactions with tobacco and cannabis use. Br J Psychiatry. 2007;191:402-7.

27. Herman AI et al. Association study of the CNR1 gene exon 3 alternative promoter region polymorphisms and substance dependence. Am J Med Genet B Neuropsychiatr Genet. 2006;141B(5): 499-503.

28. $\cdot$ Ho BC et al. Cannabinoid receptor 1 gene polymorphisms and marijuana misuse interactions on white matter and cognitive deficits in schizophrenia. Schizophr Res. 2011;128(1-3):66-75. This study demonstrates that CUDs in the context of specific CNR1 genotypes may contribute to greater brain atrophy as well as neurocognitive impairment, which may lead to increased risk for developing schizophrenia.

29. Kawamura $\mathrm{Y}$ et al. The CB1 cannabinoid receptor is the major cannabinoid receptor at excitatory presynaptic sites in the hippocampus and cerebellum. J Neurosci. 2006;26(11):2991-3001.

30. Dean B et al. Studies on $[3 \mathrm{H}] \mathrm{CP}-55940$ binding in the human central nervous system: regional specific changes in density of cannabinoid-1 receptors associated with schizophrenia and cannabis use. Neuroscience. 2001;103(1):9-15.

31. Ceccarini $\mathrm{J}$ et al. Increased ventral striatal $\mathrm{CB} 1$ receptor binding is related to negative symptoms in drug-free patients with schizophrenia. Neuroimage. 2013;79:304-12.

32. Deng $C$, Han M, Huang XF. No changes in densities of cannabinoid receptors in the superior temporal gyrus in schizophrenia. Neurosci Bull. 2007;23(6):341-7.

33. Koethe D et al. Expression of CB1 cannabinoid receptor in the anterior cingulate cortex in schizophrenia, bipolar disorder, and major depression. J Neural Transm. 2007;114(8):1055-63.

34.• Volk DW, et al. Reciprocal alterations in cortical cannabinoid receptor 1 binding relative to protein immunoreactivity and transcript levels in schizophrenia. Schizophr Res. This recent study examined $C B 1 R$ s in the PFC of schizophrenia patients using a selective $C B 1 R$ ligand. Higher CBIR binding and lower levels of $C B 1 R \mathrm{mRNA}$ and immunoreactivity were observed in patients and are thought to contribute to their increased susceptibility to cannabis.

35. De Marchi $\mathrm{N}$ et al. Endocannabinoid signalling in the blood of patients with schizophrenia. Lipids Health Dis. 2003;2:5.

36. Koethe $\mathrm{D}$ et al. Anandamide elevation in cerebrospinal fluid in initial prodromal states of psychosis. Br J Psychiatry. 2009;194(4):371-2.

37. Morgan CJ et al. Cerebrospinal fluid anandamide levels, cannabis use and psychotic-like symptoms. Br J Psychiatry. 2013;202(5): $381-2$.

38. Potvin $\mathrm{S}$ et al. Endogenous cannabinoids in patients with schizophrenia and substance use disorder during quetiapine therapy. J Psychopharmacol. 2008;22(3):262-9.

39. Leweke FM et al. Anandamide levels in cerebrospinal fluid of firstepisode schizophrenic patients: impact of cannabis use. Schizophr Res. 2007;94(1-3):29-36.

40. Leweke FM et al. Cannabidiol enhances anandamide signaling and alleviates psychotic symptoms of schizophrenia. Transl Psychiatry. 2012;2:e94.

41. Daskalakis ZJ et al. Long-interval cortical inhibition from the dorsolateral prefrontal cortex: a TMS-EEG study. Neuropsychopharmacology. 2008;33(12):2860-9.

42. Fitzgerald PB, Williams S, Daskalakis ZJ. A transcranial magnetic stimulation study of the effects of cannabis use on motor cortical inhibition and excitability. Neuropsychopharmacology. 2009;34(11):2368-75.

43. Wobrock T, et al. Increased cortical inhibition deficits in firstepisode schizophrenia with comorbid cannabis abuse. Psychopharmacology (Berl). 2010;208(3):353-63. This study compared cortical inhibition between first-episode schizophrenia patients with and without a history of cannabis abuse, and showed deficits in $G A B A_{A}$ activity as a function of CUD.

44. Daskalakis ZJ et al. Evaluating the relationship between long interval cortical inhibition, working memory and gamma band activity in the dorsolateral prefrontal cortex. Clin EEG Neurosci. 2008;39(3):150-5.

45. Uhlhaas PJ, Singer W. Abnormal neural oscillations and synchrony in schizophrenia. Nat Rev Neurosci. 2010;11(2):100-13.

46. Braff DL, Geyer MA. Sensorimotor gating and schizophrenia. Human and animal model studies. Arch Gen Psychiatry. 1990;47(2):181-8.

47. Kedzior KK, Martin-Iverson MT. Attention-dependent reduction in prepulse inhibition of the startle reflex in cannabis users and 
schizophrenia patients: a pilot study. Eur J Pharmacol. 2007;560(23):176-82.

48. Scholes KE, Martin-Iverson MT. Alterations to pre-pulse inhibition (PPI) in chronic cannabis users are secondary to sustained attention deficits. Psychopharmacology (Berl). 2009;207(3):469-84.

49. Mathias CW et al. Failure to sustain prepulse inhibition in adolescent marijuana users. Drug Alcohol Depend. 2011;116(1-3):110-6.

50. Quednow BB et al. Prepulse inhibition and habituation of acoustic startle response in male MDMA ('ecstasy') users, cannabis users, and healthy controls. Neuropsychopharmacology. 2004;29(5):98290.

51. Scholes-Balog KE, Martin-Iverson MT. Cannabis use and sensorimotor gating in patients with schizophrenia and healthy controls. Hum Psychopharmacol. 2011;26(6):373-85.

52. Geyer MA. Are cross-species measures of sensorimotor gating useful for the discovery of procognitive cotreatments for schizophrenia? Dialogues Clin Neurosci. 2006;8(1):9-16.

53. Kedzior KK, Koch M, Basar-Eroglu C. Prepulse inhibition (PPI) of auditory startle reflex is associated with PPI of auditory-evoked theta oscillations in healthy humans. Neurosci Lett. 2006;400(3):246-51.

54. Skosnik PD, Spatz-Glenn L, Park S. Cannabis use is associated with schizotypy and attentional disinhibition. Schizophr Res. 2001;48(1):83-92.

55. Bramon E et al. Meta-analysis of the P 300 and P50 waveforms in schizophrenia. Schizophr Res. 2004;70(2-3):315-29.

56. Patrick G, Struve FA. Reduction of auditory P50 gating response in marihuana users: further supporting data. Clin Electroencephalogr. 2000;31(2):88-93.

57. Rentzsch J et al. Differential impact of heavy cannabis use on sensory gating in schizophrenic patients and otherwise healthy controls. Exp Neurol. 2007;205(1):241-9.

58. Edwards CR et al. Sensory gating impairments in heavy cannabis users are associated with altered neural oscillations. Behav Neurosci. 2009;123(4):894-904.

59. Skosnik PD et al. The effect of chronic cannabinoids on broadband EEG neural oscillations in humans. Neuropsychopharmacology. 2012;37(10):2184-93

60. Yucel $\mathrm{M}$ et al. Regional brain abnormalities associated with longterm heavy cannabis use. Arch Gen Psychiatry. 2008;65(6):694-701.

61. Rabin RA, Zakzanis KK, George TP. The effects of cannabis use on neurocognition in schizophrenia: a meta-analysis. Schizophr Res. 2011;128(1-3):111-6.

62. Ferraro L et al. Cannabis users have higher premorbid IQ than other patients with first onset psychosis. Schizophr Res. 2013;150(1): 129-35.

63. Rabin RA et al. Effects of cannabis use status on cognitive function, in males with schizophrenia. Psychiatry Res. 2013;206(2-3):15865. This study examined the relationship between cumulative cannabis use and cognition in current and former cannabis users with schizophrenia. Findings demonstrated the cognitive-impairing effects of cannabis, and that these deficits may be reversible with sustained abstinence.

64. Mackay AV et al. Increased brain dopamine and dopamine receptors in schizophrenia. Arch Gen Psychiatry. 1982;39(9):991-7.

65. Di Chiara G, Imperato A. Drugs abused by humans preferentially increase synaptic dopamine concentrations in the mesolimbic system of freely moving rats. Proc Natl Acad Sci U S A. 1988;85(14): 5274-8.

66. Weinshilboum RM, Otterness DM, Szumlanski CL. Methylation pharmacogenetics: catechol O-methyltransferase, thiopurine methyltransferase, and histamine N-methyltransferase. Annu Rev Pharmacol Toxicol. 1999;39:19-52.

67. Caspi A et al. Moderation of the effect of adolescent-onset cannabis use on adult psychosis by a functional polymorphism in the catechol-O-methyltransferase gene: longitudinal evidence of a gene X environment interaction. Biol Psychiatry. 2005;57(10):1117-27.
68. Henquet $\mathrm{C}$ et al. An experimental study of catechol-omethyltransferase Val158Met moderation of delta-9-tetrahydrocannabinol-induced effects on psychosis and cognition. Neuropsychopharmacology. 2006;31(12):2748-57.

69. Bozzi Y, Dunleavy M, Henshall DC. Cell signaling underlying epileptic behavior. Front Behav Neurosci. 2011;5:45.

70. Thiselton DL et al. AKT1 is associated with schizophrenia across multiple symptom dimensions in the Irish study of high density schizophrenia families. Biol Psychiatry. 2008;63(5):449-57.

71. Sanchez MG et al. Activation of phosphoinositide 3-kinase/PKB pathway by $\mathrm{CB}(1)$ and $\mathrm{CB}(2)$ cannabinoid receptors expressed in prostate PC-3 cells. Involvement in Raf-1 stimulation and NGF induction. Cell Signal. 2003;15(9):851-9.

72. van Winkel R, Genetic Risk and Outcome of Psychosis (GROUP) Investigators. Family-based analysis of genetic variation underlying psychosis-inducing effects of cannabis: sibling analysis and proband follow-up. Arch Gen Psychiatry. 2011;68(2):148-57.

73. Di Forti M et al. Confirmation that the AKT1 (rs2494732) genotype influences the risk of psychosis in cannabis users. Biol Psychiatry. 2012;72(10):811-6.

74. van Winkel R et al. AKT1 moderation of cannabis-induced cognitive alterations in psychotic disorder. Neuropsychopharmacology. 2011;36(12):2529-37.

75. Bhattacharyya $\mathrm{S}$ et al. Preliminary report of biological basis of sensitivity to the effects of cannabis on psychosis: AKT1 and DAT1 genotype modulates the effects of delta-9. tetrahydrocannabinol on midbrain and striatal function. Mol Psychiatry. 2012;17(12):1152-5.

76. Fornito A et al. Mapping grey matter reductions in schizophrenia: an anatomical likelihood estimation analysis of voxel-based morphometry studies. Schizophr Res. 2009;108(1-3):104-13.

77. Pantelis $\mathrm{C}$ et al. Neuroanatomical abnormalities before and after onset of psychosis: a cross-sectional and longitudinal MRI comparison. Lancet. 2003;361(9354):281-8.

78. Matochik JA et al. Altered brain tissue composition in heavy marijuana users. Drug Alcohol Depend. 2005;77(1):23-30.

79. Demirakca $T$ et al. Diminished gray matter in the hippocampus of cannabis users: possible protective effects of cannabidiol. Drug Alcohol Depend. 2011;114(2-3):242-5.

80. Quickfall J, Crockford D. Brain neuroimaging in cannabis use: a review. J Neuropsychiatry Clin Neurosci. 2006;18(3):318-32.

81. Szeszko PR et al. Anterior cingulate grey-matter deficits and cannabis use in first-episode schizophrenia. Br J Psychiatry. 2007;190: 230-6.

82. Bangalore SS et al. Cannabis use and brain structural alterations in first episode schizophrenia: a region of interest, voxel based morphometric study. Schizophr Res. 2008;99(1-3):1-6.

83. James A et al. Greater white and grey matter changes associated with early cannabis use in adolescent-onset schizophrenia (AOS). Schizophr Res. 2011;128(1-3):91-7.

84. Solowij $\mathrm{N}$ et al. Cerebellar white-matter changes in cannabis users with and without schizophrenia. Psychol Med. 2011;41(11):2349-59.

85. Wobrock $\mathrm{T}$ et al. Comorbid substance abuse and brain morphology in recent-onset psychosis. Eur Arch Psychiatry Clin Neurosci. 2009;259(1):28-36.

86. Smith MJ et al. Cannabis-related working memory deficits and associated subcortical morphological differences in healthy individuals and schizophrenia subjects. Schizophr Bull. 2014;40(2):28799. This study assessed the association of CUDs with subcortical structures implicated in working memory. Both patients and controls experienced similar differences in brain morphology associated with cannabis use. Deficits were exaggerated in patients, suggesting heightened sensitivity to cannabis in schizophrenia.

87. Rais $\mathrm{M}$ et al. Excessive brain volume loss over time in cannabisusing first-episode schizophrenia patients. Am J Psychiatry. 2008;165(4):490-6. 
88. Hermann D, Schneider M. Potential protective effects of cannabidiol on neuroanatomical alterations in cannabis users and psychosis: a critical review. Curr Pharm Des. 2012;18(32): 4897-905.

89. Uhlhaas PJ et al. Neural synchrony and the development of cortical networks. Trends Cogn Sci. 2010;14(2):72-80.

90. Mato $\mathrm{S}$ et al. A single in-vivo exposure to delta 9THC blocks endocannabinoid-mediated synaptic plasticity. Nat Neurosci. 2004;7(6):585-6.
91. Ade KK, Lovinger DM. Anandamide regulates postnatal development of long-term synaptic plasticity in the rat dorsolateral striatum. J Neurosci. 2007;27(9):2403-9.

92. de Oliveira Alvares L et al. Amnestic effect of intrahippocampal AM251, a CB1-selective blocker, in the inhibitory avoidance, but not in the open field habituation task, in rats. Neurobiol Learn Mem. 2005;83(2):119-24.

93. Crespo-Facorro B et al. Neuropsychological functioning and brain structure in schizophrenia. Int Rev Psychiatry. 2007;19(4):325-36. 